\title{
Light Enhancement of Solar Module
}

\author{
Hsin-Hsin Hsieh1, Jen-Loong Hwang1, Chia-Yu Lin' ${ }^{2}$ Jang-Hsing Hsieh' \\ ${ }^{1}$ Green Energy \& Environment Research Lab, Industrial Technology Research Institute, Hsinchu City, Chinese \\ Taipei \\ ${ }^{2}$ Department of Materials Engineering, Ming-Chi University of Technology, New Taipei, Chinese Taipei \\ Email: minahsieh@itri.org.tw
}

Received 30 September 2014; revised 28 October 2014; accepted 16 November 2014

Copyright (C) 2014 by authors and Scientific Research Publishing Inc.

This work is licensed under the Creative Commons Attribution International License (CC BY).

http://creativecommons.org/licenses/by/4.0/

(c) (i) Open Access

\begin{abstract}
This paper presents sputtered-deposited Ag nanoparticles (NPs) on the encapsulant material (ethylene vinyl acetate, EVA) with the variation of annealing condition on crystalline silicon solar cell to enhance the light intensity, and a conventional solar cell is also performed for comparison. It was found that an increase in the transmittance at the wavelength of $500-800 \mathrm{~nm}$ was detected in the Ag nanoparticle solar cells. And red-light enhancement of around 2\% was measured in the Ag-sputtered solar module under annealing condition of $700^{\circ} \mathrm{C}$ for $3 \mathrm{~min}$ from incident photon to converted electron (IPCE) profile. The photovoltaic performance of solar modules was characterized by a flasher system in AAA class (temporal instability, spectral match, and irradiance nonuniformity). The IV curve showed a current enhancement with Ag-EVA sample, and thus a high power output around $0.250 \mathrm{~W}$ was observed. A high fill factor of $73.63 \%$ also implied a high performance in series and shunt resistance. Surface plasmonic resonance effects of Ag nanoparticles deposited on the surface of solar cell were examined and discussed. This paper not only illustrated the performance of the surface plasmonic resonance of a solar device but also verified the application in the industrial production.
\end{abstract}

\section{Keywords}

Light Enhancement, Solar Module, Ag Nanoparticles

\section{Introduction}

Renewable energy has become a blooming trend on both academic research and industrial production due to the limited natural energy resources. Photovoltaic technology is especially focused on its environmental-friendliness and long-term application. According to the reports of concerning the estimates the solar technology and installation capacity [1] [2], crystalline solar technology is still the main stream at a percentage of 86\% in year 2012, and keeps growing $>90 \%$ till year 2020. However, high conversion efficiency is the most important issue that researchers and industry are working on for a significant improvement. Aside from n-type wafer technology 
which increases the minority carrier lifetime [3] [4], the enhancement of optics is an efficient solution for improving the solar cell efficiency. According to the previous literature [5] [6], optical enhancement can be approached by producing light trapping effect on the cell surface and depositing anti-reflection coating on the surface. These technologies are applied to increase the reflectance path in the solar device; furthermore, an even efficient way to enhance the absorption is to produce surface plasmonic resonance effect [7] on the cell surface. Theoretically, surface surface plasmonic resonance effect is an optical phenomena generated by light when it interacts with conductive NPs that are smaller than the incident wavelength. As in surface plasmon resonance, the electric field of incident light can be deposited to collectively excite electrons of a conduction band, with the result being coherent localized plasmon oscillations with a resonant frequency that strongly depends on the composition, size, geometry, dielectric environment and separation distance of NPs. It is reported that Ag-nanoparticles deposited on $\mathrm{ZnO}$ layer can improve the surface absorption at the wavelength of 550 - $800 \mathrm{~nm}$, thus an increase of $14 \%$ in current density is approved for thin film solar cell [7] [8]. However, the application of surface plasmonic effect on crystalline solar cell is quite limited, and the availability on solar module process has not been studied. This study is to realize the surface plasmonic resonance of Ag nanoparticles on crystalline solar cell and the module performance is also proved.

\section{Experimental}

Ag films are prepared by a sputtering system and deposited on $\mathrm{SiO}_{2}$ quartz substrate $(5 \mathrm{~cm} \times 5 \mathrm{~cm})$. The sputtering mechanism of Ag films is shown in Figure 1 and detailed sputtering parameters are shown in Table 1. The sputtered Ag film was around $100 \mathrm{~nm}$ in thickness and then processed with rapid annealing to form granular silver nanoparticles. The rapid annealing conditions were set to $700^{\circ} \mathrm{C}$ and $800^{\circ} \mathrm{C}$ for $2 \mathrm{~min}$ and $3 \mathrm{~min}$. After annealing, surface morphology of Ag NPs in various annealing condition are analyzed by scanning electron microscope (JEOL, JSM 6701F).

The preparation of the solar module is illustrated in Figure 2. A pre-cure EVA film as initial cross-linked reaction is laminated at temperature of $150^{\circ} \mathrm{C}$ for 15 minutes. And the pre-cured EVA is covered on the annealed silver nanoparticles which are deposited on quartz, and then laminated at $150^{\circ} \mathrm{C}$ for 20 minutes. The EVA is peeled from the quartz, thus the Ag NPs were transferred from the quartz and adhere on the EVA surface. The Ag-contained EVA was measured by UV spectrometer (HITACHI, U-4100) to obtain the optical properties. The photovoltaic performance of solar modules was characterized by a flasher system in AAA class (temporal instability, spectral match, and irradiance non-uniformity), and electroluminescent instrument (EL, Hong-Ming Technology, SWIR-320DE3) was also performed to realize the electrical distribution image of solar module [9].

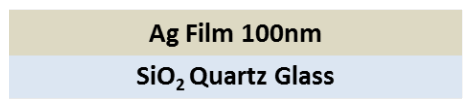

(a)

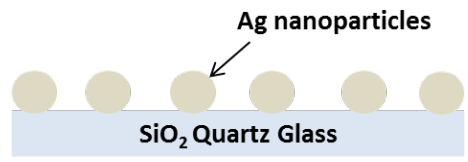

(b)

Figure 1. Schematic of sputtering Ag (a) before and (b) after annealing.

Table 1. Parameters of sputtering Ag nanoparticles.

\begin{tabular}{cc} 
Parameters & Value \\
\hline Ag pwer & $40 \mathrm{~W}$ \\
Background pressure & $4.8 \times 10^{-6}$ torr \\
Working pressure & $7.0 \times 10^{-6}$ torr \\
Target-substrate distance & $10 \mathrm{~cm}$ \\
Substrate temperature & Room temperature \\
Thickness & $100 \mathrm{~nm}$ \\
Ar flow rate & $35 \mathrm{sccm}$ \\
\hline
\end{tabular}




\section{Characterization and Analyses}

\subsection{Optical Analyses}

EVA containing nano silver particles through the transfer printing process after (Ag-EVA) light transmittance shown in Figure 3. In general, the Ag-EVA sample annealed at $700^{\circ} \mathrm{C}$ for 3 min shows a highest transmittance, it is worth to note that at a wavelength of $>450 \mathrm{~nm}$ and higher than reference curves showing a sample of this Ag-EVA annealing conditions have the effect of improving the degree of penetration, the $800^{\circ} \mathrm{C}$ annealing AgEVA sample of 2 minutes of penetration is mainly to enhance the long-wavelength ( $>780 \mathrm{~nm}$ ), compared to $700^{\circ} \mathrm{C}$ annealing 2 minutes and low penetration of analysis results $800^{\circ} \mathrm{C}$ annealing 3 minutes of Ag-EVA, we can see $700^{\circ} \mathrm{C}$ annealing 3 minutes of the Ag-EVA with better light transmission.

\subsection{Surface Morphology}

Figure 4 illustrates surface topography analysis of the Ag nanoparticles on quartz before and after transferring. From the figure can be found, turn prepress $700^{\circ} \mathrm{C}$ annealing process which forms the shape of the Ag NPs irregular granular, annealing 3 minutes of the silver particles are dispersed more evenly and the diameter is about $150 \mathrm{~nm}$. Ag NPs annealed at $800^{\circ} \mathrm{C}$ for 2 minutes are nearly circular shape, and distribution is denser. $800^{\circ} \mathrm{C}$ annealing 3 minutes of the silver particles exhibit irregular and uneven distribution. In fact, according to the previous literature [9] [10], the shape of the Ag NPs can be found in light trapping effect is closer to a circle to achieve the effect of the optical gain. Comparison of the observed SEM images, of four annealing conditions for Ag nanoparticles, $700^{\circ} \mathrm{C}-3$ minutes annealing treatment exhibits uniform particle size and well distribution, thereby the higher optical enhancement.

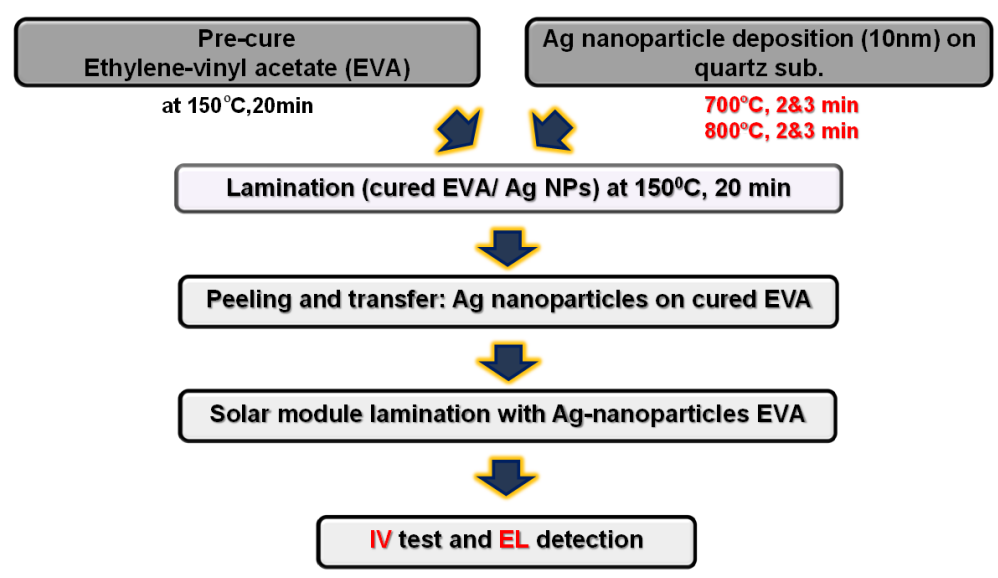

Figure 2. Preparation of device with Ag NPs.

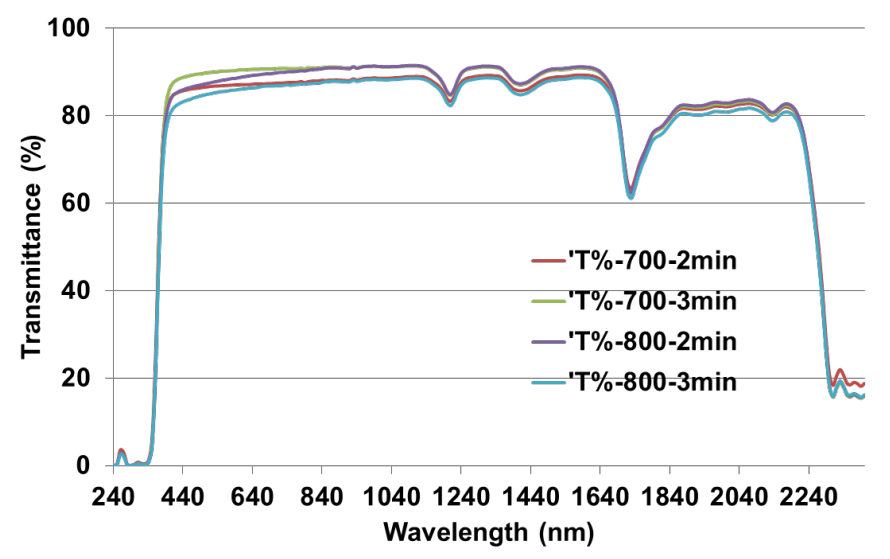

Figure 3. Transmittance of EVA sputtered Ag nanoparticles in various annealing conditions. 


\subsection{Performance of Device}

Figure 5 depicts the performance of Ag-EVA on crystalline solar cell, and the electrical characters are shown in Table 2. It is observed that variation in Isc is more significant than that in Voc, suggesting that surface plas-

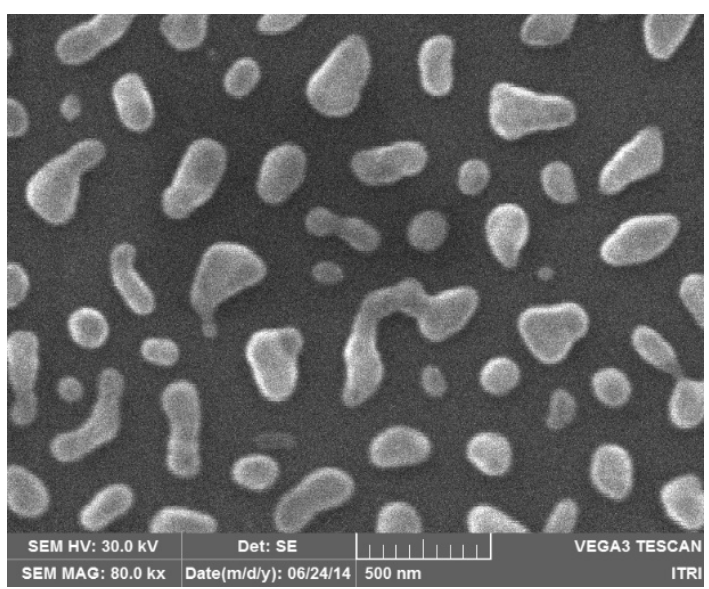

(a)

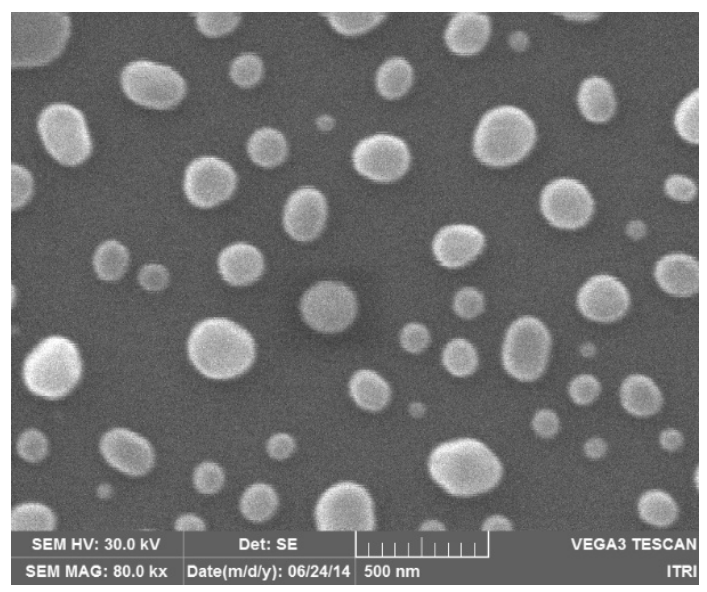

(c)

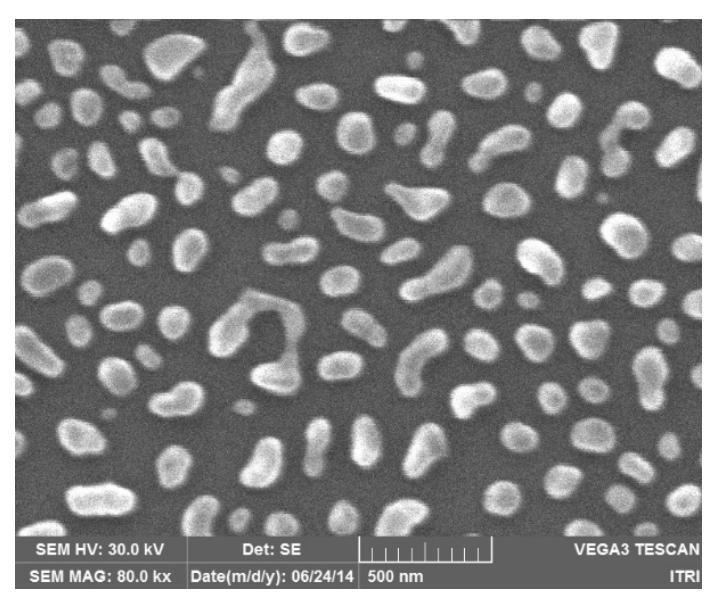

(b)

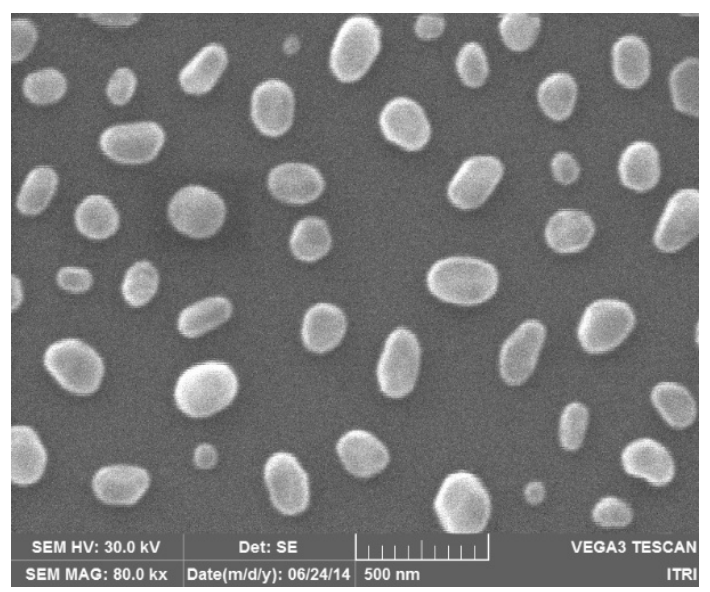

(d)

Figure 4. SEM images of Ag nanoparticles before transferring: (a) Annealing $700^{\circ} \mathrm{C}-2 \mathrm{~min}$; (b) Annealing $700^{\circ} \mathrm{C}-3 \mathrm{~min}$; (c) Annealing $800^{\circ} \mathrm{C}-2 \mathrm{~min}$, and (d) Annealing $800^{\circ} \mathrm{C}-3 \mathrm{~min}$.

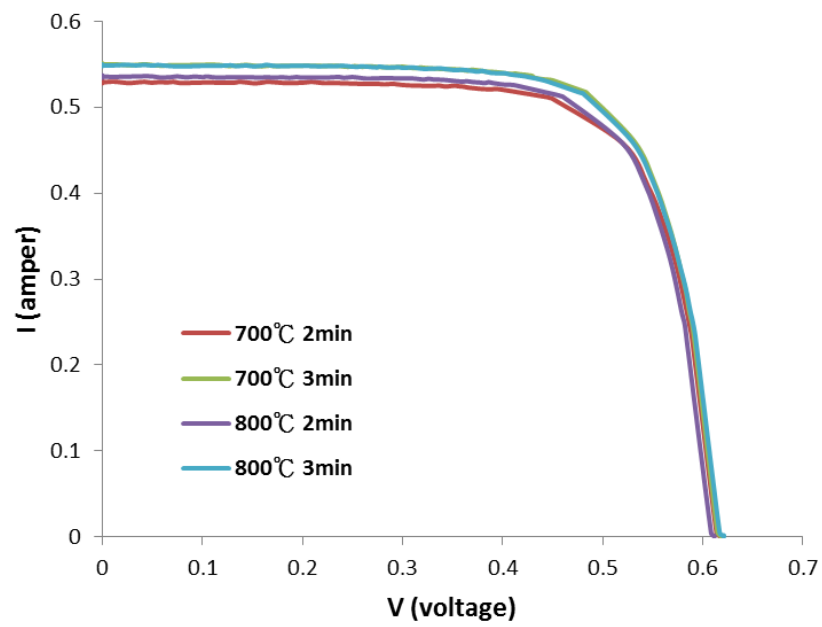

Figure 5. IV curve of EVA sputtered Ag nanoparticles in various annealing conditions. 
Table 2. Electrical performance of Ag-EVA on crystalline solar cell.

\begin{tabular}{ccccccc}
\hline Annealing & Rs $(\mathrm{Ohm})$ & Rsh $(\mathrm{Ohm})$ & Pmax (W) & Voc (V) & Isc (A) & FF (\%) \\
\hline $700^{\circ} \mathrm{C}-2 \mathrm{~min}$ & 0.385 & 0.026 & 0.238 & 0.618 & 0.530 & 72.85 \\
$700^{\circ} \mathrm{C}-3 \mathrm{~min}$ & 0.284 & 0.020 & 0.250 & 0.618 & 0.550 & 73.63 \\
$800^{\circ} \mathrm{C}-2 \mathrm{~min}$ & 0.337 & 0.030 & 0.238 & 0.612 & 0.536 & 72.65 \\
$800^{\circ} \mathrm{C}-3 \mathrm{~min}$ & 0.300 & 0.024 & 0.248 & 0.621 & 0.549 & 72.74 \\
\hline
\end{tabular}

monic resonance enhances the light performance of solar module. $700^{\circ} \mathrm{C}-3$ min sample shows a high Isc of $0.550 \mathrm{~A}$; thus a high power output around $0.250 \mathrm{~W}$ was observed. And a high fill factor of $73.63 \%$ implies a high performance in series and shunt resistance was demonstrated. According to the IV measurement of solar module containing Ag-EVA, it is confirmed that the optical enhancement can be realized in solar module and the power output increased of $4.7 \%$.

\section{Conclusions}

This study is to discuss the surface plasmonic resonance effect of Ag nanoparticles on the solar cell and module. Research results can be addressed as below:

1) With an annealing condition of $700^{\circ} \mathrm{C}$ for $3 \mathrm{~min}$, surface plasmonic resonance effect of Ag nanoparticles is significantly observed with high transmittance of higher than $90 \%$ at wavelength $500-800 \mathrm{~nm}$.

2) According to SEM morphology, the optimized surface plasmonic resonance effect is observed at particle size of $150 \mathrm{~nm}$ in diameter. The uniformity of and distribution of nanoparticles should also affect the light trapping effect of solar module, thus a high Isc is shown in the IV curve.

3) IV curve demonstrates that the Ag-EVA crystalline solar module has a lower series resistance, higher shunt resistance, and high fill factor. And the optical enhancement contributed by the Ag NPs is proven to increase the power output of $4.7 \%$ compared to traditional solar cell.

\section{Acknowledgements}

The financial support provided by Bureau of Energy is gratefully acknowledged.

\section{References}

[1] (2013) Navigant Consulting; for 2012: Estimate from Different Sources (Navigant and IHS). Graph: PSE AG.

[2] (2014) International Technology Roadmap for Photovoltaic, ITRPV.

[3] Feldmann, F., Bivour, M., Reichel, C., Hermle, M. and Glunz, S.W. (2014) Passivated Rear Contacts for High-Efficiency n-Type Si Solar Cells Providing High Interface Passivation Quality and Excellent Transport Characteristics. Solar Energy Materials and Solar Cells, 120, 270-274. http://dx.doi.org/10.1016/j.solmat.2013.09.017

[4] Jay, F., Muñoz, D., Desrues, T., Pihan, E., Amaral de Oliveira, V., Enjalbert, N. and Jouini, A. (2014) Advanced process for n-Type Mono-Like Silicon a-Si:H/c-Si Heterojunction Solar Cells with 21.5\% Efficiency. Solar Energy Materials and Solar Cells, 130, 690-695. http://dx.doi.org/10.1016/j.solmat.2014.02.025

[5] Chang, C.H., Hsu, M.H., Chang, W.L., Sun, W.C., Wu, C.W. and Yu, P. (2010) Enhanced Angular Response of Power Conversion Efficiency for Silicon Solar Cells Utilizing a Uniformly Distributed Nano-Whisker Medium. Proceedings of 35th IEEE Photovoltaic Specialists Conference, Honolulu, 20-25 June 2010, 003109-003111. http://dx.doi.org/10.1109/PVSC.2010.5614544

[6] Sánchez-Illescas, P.J. Carpena, P., Bernaola-Galván, P., Sidrach-de-Cardona, M., Coronado, A.V. and Àlvarez, J.L. (2008) An Analysis of Geometrical Shapes for PV Module Glass Encapsulation. Solar Energy Materials \& Solar Cells, 92, 323-331. http://dx.doi.org/10.1016/j.solmat.2013.09.017

[7] Ferry, V., Verschuuren, M.A., Li, H., Verhagen, E., Walters, R.J., Schropp, R.E.I., Atwater, H.A. and Polman, A. (2010) Light Trapping in Ultrathin Plasmonic Solar Cells. Optics express, 18, A237-A245. http://dx.doi.org/10.1364/OE.18.00A237

[8] Harry, A. and Polman, A. (2010) Plasmonics for Improved Photovoltaic Devices. Nature Materials, 9, 205-213. http://dx.doi.org/10.1038/nmat2629

[9] Fuyuki, T., Kondo, H., Yamazaki, T., Takahashi, Y. and Uraoka, Y. (2005) Photographic Surveying of Minority Carri- 
er Diffusion Length in Polycrystalline Silicon Solar Cells by Electroluminescence. Applied Physics Letters, 86, 262108. http://dx.doi.org/10.1063/1.1978979

[10] Mizuno, M., Tsai, H., Matsubara, K. and Kondo, M. (2012) Light Trapping by Ag Nanoparticles Chemically Assembled inside Thin-Film Hydrogenated Microcrystalline Si Solar Cells. Japanese Journal of Applied Physics, 51, 042302. http://dx.doi.org/10.7567/JJAP.51.042302 
Scientific Research Publishing (SCIRP) is one of the largest Open Access journal publishers. It is currently publishing more than 200 open access, online, peer-reviewed journals covering a wide range of academic disciplines. SCIRP serves the worldwide academic communities and contributes to the progress and application of science with its publication.

Other selected journals from SCIRP are listed as below. Submit your manuscript to us via either submit@scirp.org or Online Submission Portal.
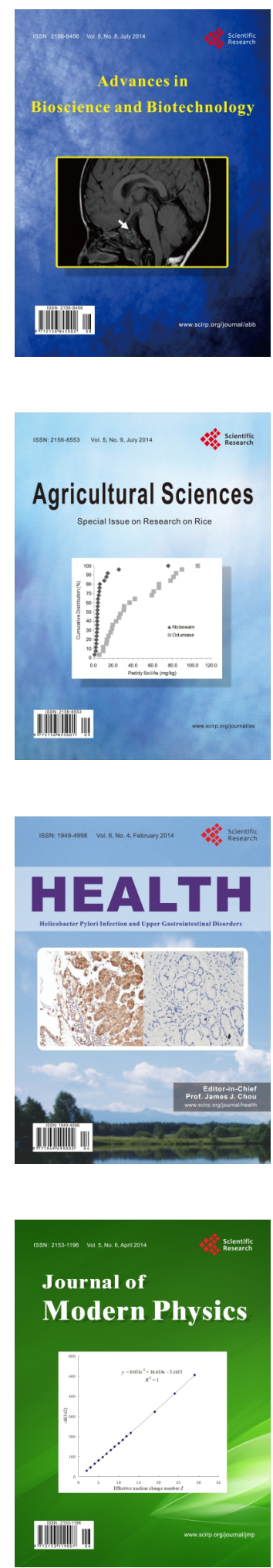
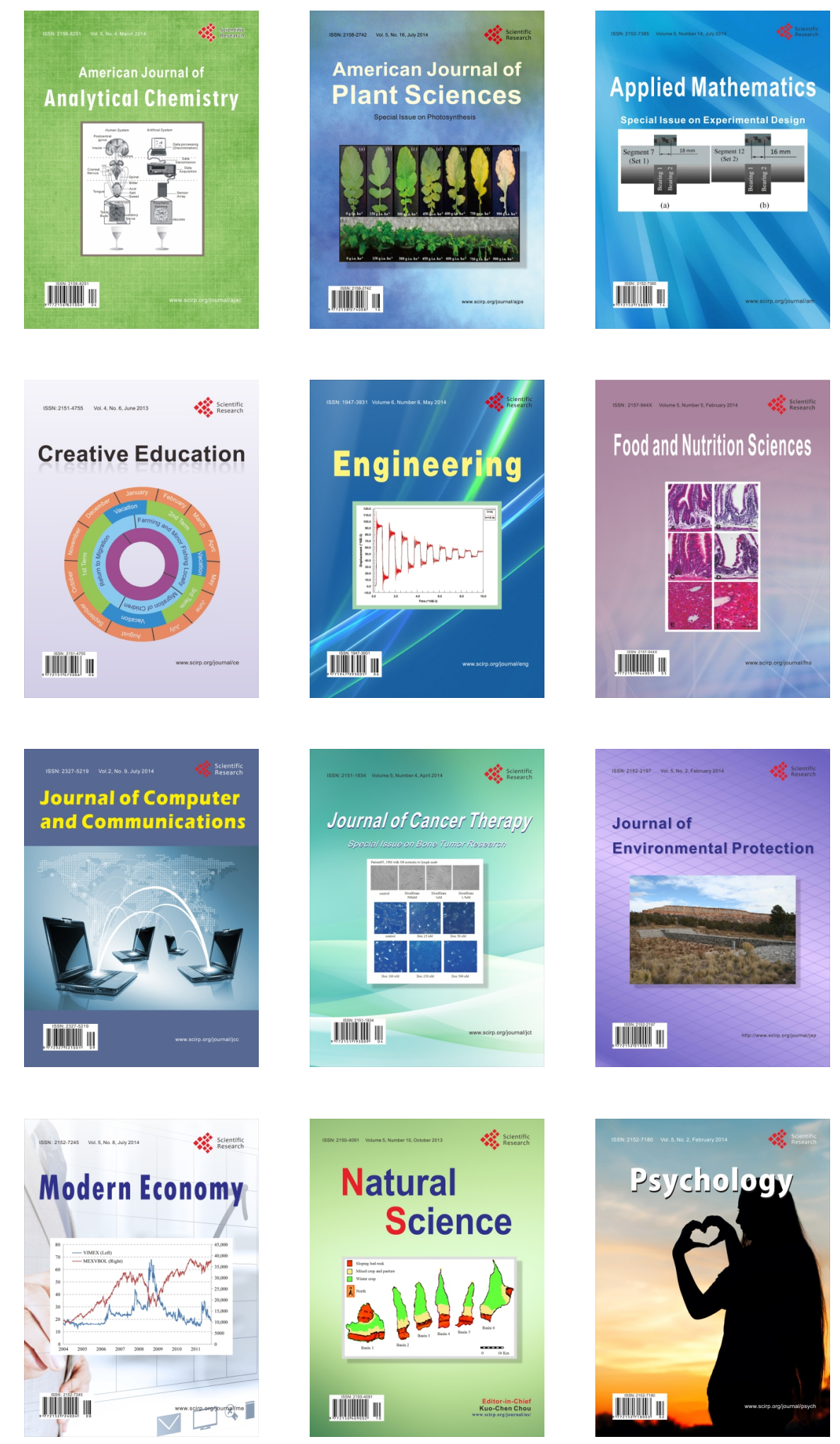